\title{
Tissue Dependence and Differential Cordycepin Sensitivity of Race-Specific Resistance Responses in the Barley-Powdery Mildew Interaction
}

\author{
Ruth Schiffer, ${ }^{1}$ Regina Görg, ${ }^{2}$ Birgit Jarosch, ${ }^{1}$ Uli Beckhove, ${ }^{1}$ Gregor Bahrenberg, ${ }^{2}$ Karl-Heinz Kogel, ${ }^{1}$ \\ and Paul Schulze-Lefert ${ }^{3}$ \\ ${ }^{1}$ Institut für Phytopathologie und Angewandte Zoologie, Justus-Liebig-Universität Giessen, Ludwigstr. 23, \\ D-35390 Giessen, Germany; ${ }^{2}$ Institut für Biologie I, Technical University of Aachen, Worringer Weg, \\ D-52074 Aachen, Germany; ${ }^{3}$ The Sainsbury Laboratory, Norwich Research Park, Colney, Norwich NR4 \\ $7 \mathrm{UH}, \mathrm{UK}$ \\ Received 13 March 1997. Accepted 31 May 1997.
}

Epidermal cell monolayers prepared from partially dissected barley (Hordeum vulgare) coleoptiles were used for in vivo analysis of race-specific resistance to powdery mildew (Erysiphe graminis f. sp. hordei) specified by host genes Mla-1, Mla-12, and Mlg. Complete resistance governed by each of these genes is closely associated with hypersensitive cell death (hypersensitive response, HR) in primary leaf tissue. In contrast, Mla-12 coleoptile tissue reveals a fully compatible, $M l a-1$ coleoptile tissue a partially compatible, and $\mathrm{Mlg}$ coleoptile tissue an incompatible interaction upon challenge with pathogen races carrying corresponding avirulence functions. Quantitative recording of single plant-fungus interaction sites showed arrest of fungal development in papillae on $\mathrm{Mlg}$ coleoptiles. On Mla-1 and Mla-12 coleoptiles, attacked cells become predominantly penetrated by the fungus. Approximately one third of penetrated cells on Mla-1 coleoptiles subsequently undergo an HR. These sites reveal no further fungal development. Both $M l g$ and $M l a-12$ coleoptiles fail to mount an HR. The effect of cordycepin ( $3^{\prime}$-deoxyadenosine), an inhibitor of mRNA synthesis, was studied in planta on primary leaf tissue of Mla-12 and Mlg genotypes. Host cell death triggered by either gene is reduced to background levels observed in the near-isogenic compatible interaction and exhibits the same dose-dependent cordycepin sensitivity. Inhibition of $M l g$-triggered, singlecell $\mathrm{HR}$ is not accompanied by release of fungal growth arrest, indicating cordycepin insensitivity of a papillaeassociated resistance component. The data suggest that host cell death is a requisite component for expression of Mla-type but not Mlg-type resistance.

Powdery mildew is a major disease of monocotyledonous and dicotyledonous plants in temperate climates. In barley, the

Corresponding authors: K.-H. Kogel; Telephone: +49 64199 37491; Fax: +49 64199 37499; P. Schulze-Lefert; Fax: +44 1603 250024; E-mail: schlef@bbsrc.ac.uk

Ruth Schiffer and Regina Görg made equal contributions to this work disease is caused by Erysiphe graminis f. sp. hordei, an obligate, biotrophic fungus that exclusively attacks epidermal leaf tissue. The outcome of the interaction, resistance or susceptibility, usually obeys the rules of the gene-for-gene concept (Flor 1971): resistance is dependent on and specified by the presence of two complementary genes, one from the host and one from the fungal pathogen. In barley, a multitude of racespecific powdery mildew resistance genes have been identified and characterized; they are predominantly inherited as dominant or partially dominant acting traits (Wiberg 1974).

Developmental stages of E. graminis during pathogen attack are well defined; fungal spores show a synchronized development upon leaf inoculation (Aist and Bushnell 1991; Carver 1988). After contact of the spore with the wax layer of a barley leaf, the following fungal structures differentiate within the first $24 \mathrm{~h}$ postinoculation (hpi) (Ellingboe 1972): the primary germ tube ( 1 to $2 \mathrm{hpi}$ ); the appressorial germ tube with a mature appressorium (some 10 to $12 \mathrm{hpi}$ ); and the haustorium (some 18 to $24 \mathrm{hpi}$ ), which invaginates the epidermal plasma membrane. Formation of aerial mycelium and sporulation are late differentiation events between 4 and 7

Table 1. Infection types of primary leaves and epidermal monolayers of coleoptiles from barley lines derived from cv. Pallas with introgressed Mla-1, Mla-12, or Mlg resistance gene ${ }^{\mathrm{a}}$

\begin{tabular}{|c|c|c|c|c|c|c|}
\hline \multirow[b]{3}{*}{ Race } & \multicolumn{6}{|c|}{ Infection type } \\
\hline & \multicolumn{3}{|c|}{ Primary leaf ${ }^{b}$} & \multicolumn{3}{|c|}{ Coleoptile $^{c}$} \\
\hline & Mla-1 & Mla-12 & Mlg & Mla-1 & Mla-12 & Mlg \\
\hline$\overline{A 6^{\mathrm{d}}}$ & 4 & 0 & 0 & $\mathrm{ND}^{\mathrm{e}}$ & 4 & 0 to 1 \\
\hline $\mathrm{C} 15^{\mathrm{d}}$ & 0 & 3 to 4 & 1 to 2 & 2 to 3 & ND & ND \\
\hline
\end{tabular}

${ }^{a}$ No significant differences in infection types were found when BC Ingrid was tested.

${ }^{b}$ Seven-day-old plants were inoculated with the respective race of $E g h$ and infection types were evaluated, 5 days later, according to Andersen and Torp (1986).

${ }^{c}$ Coleoptiles were prepared from 10-day-old seedlings. The epidermal monolayer was inoculated with $E g h$ and infection types were evaluated 5 days later.

${ }^{\mathrm{d}}$ Race A6 carries the avirulence genes avr Mla-12 and avr Mlg, race C15 contains avr Mla-1.

e No data. 


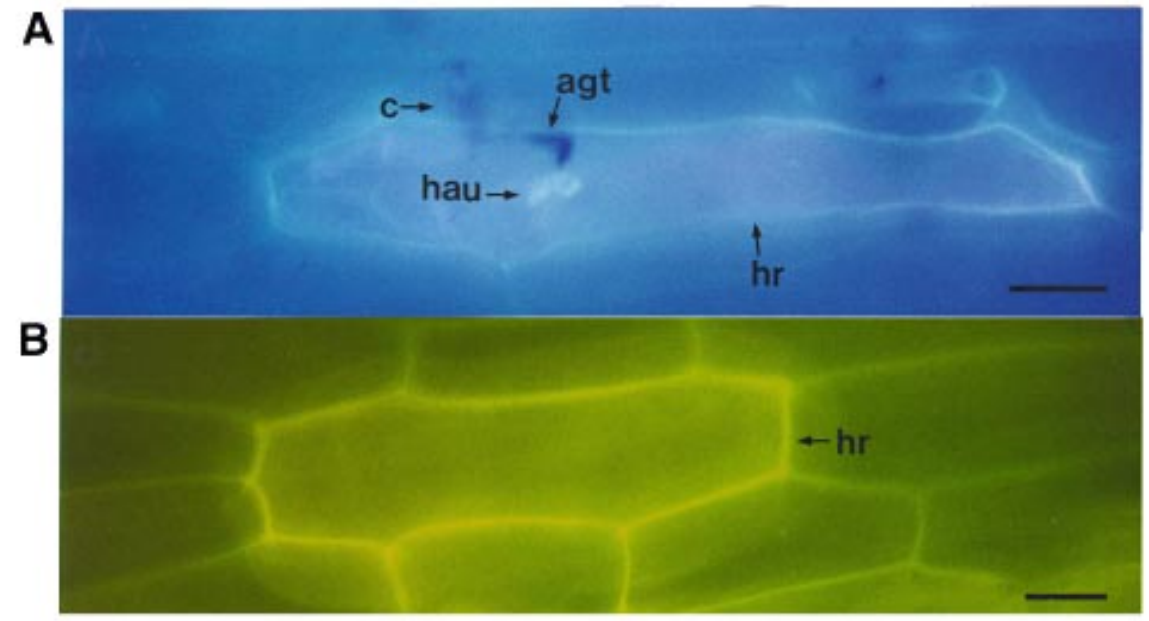

C

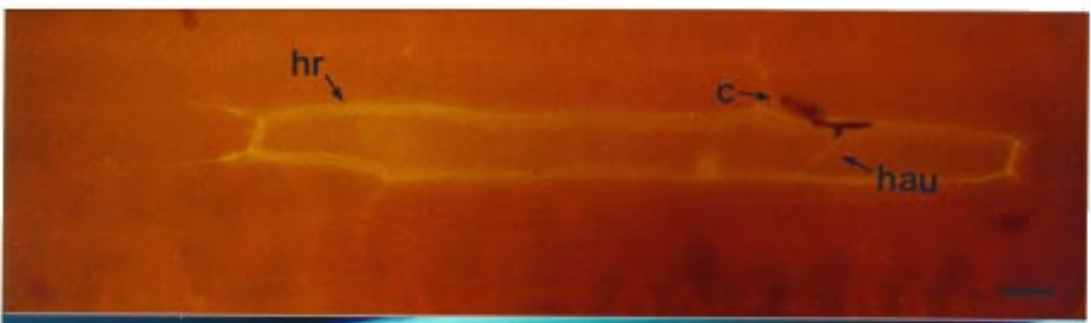

D

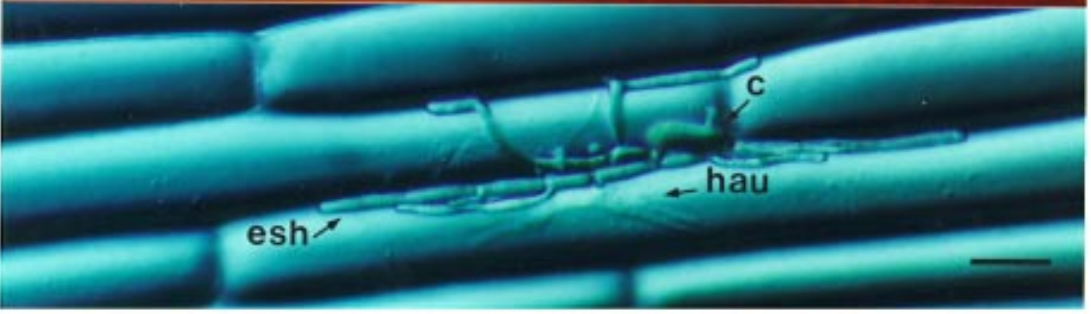

leaf

Mla-12

coleoptile

coleoptile

\section{E \\ F}
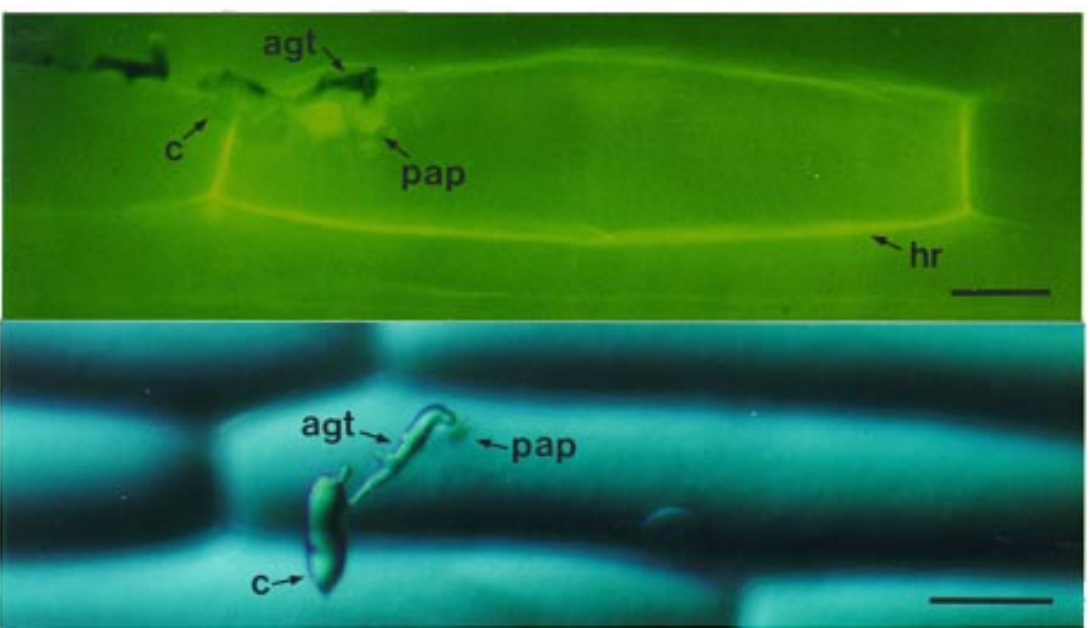

leaf

coleoptile

Fig. 1. Light microscopic display of selected Mla-1-, Mla-12-, and Mlg-mediated, single-cell resistance responses to Erysiphe graminis f. sp. hordei in barley. Primary leaves and epidermal monolayers of coleoptiles were inoculated with spores of the respective avirulent powdery mildew race and were analyzed $48 \mathrm{~h}$ after inoculation. Primary leaves (A,C,E) and coleoptiles (B,D,F) from Mla-1 (A,B), Mla-12 (C,D), and Mlg (E,F) backcross lines in cv. Pallas. Extracellular fungal structures on leaves are stained with Coomassie blue. Fungal development proceeds to formation of a haustorium only in the presence of Mla-1 and Mla-12, whereas Mlg confers growth arrest in a papilla.The Mla-12 gene is functional only in primary leaves but not in the coleoptile tissue agt $=$ appresorial germ tube; $\mathrm{c}=$ conidium; esh $=$ elongated secondary hypha; hau $=$ haustorium; hr $=$ hypersensitive cell death; pap $=$ papilla; pgt $=$ primary germ tube. Scale bars $=20 \mu \mathrm{m}$. 
days postinoculation (dpi). The establishment of the haustorium represents a key step for successful fungal reproduction because only this organ has direct contact with a host cell and serves to feed the pathogen. Quantitative cytological recordings of incompatible interactions have revealed putative host cell resistance responses conferring arrest of fungal development at distinct stages (Kita et al. 1981; Koga et al. 1988, 1990). Two of these host cell responses are easily detected: a subcellular, restricted, highly localized cell wall reinforcement at sites of attempted penetration (effective papillae), and the active, rapid death of attacked epidermal cells (hypersensitive response, HR), indicated by whole cell autofluorescence (Aist and Israel 1986; Görg et al. 1993; Koga et al. 1990). Because the function of these prominent defense responses with respect to inhibition of fungal development is still unclear, it is important to develop simplified models that enable further dissection of the complex situation in infected leaf tissue.

In primary leaves of barley seedlings, the race-specific resistance responses specified by the resistance loci Mla-1, Mla12 , and $\mathrm{Mlg}$ are accompanied by HR of epidermal cells attacked by powdery mildew races carrying corresponding avirulence genes. A time-course analysis of the early infection process in $\mathrm{Mlg}$ genotypes combined with gene dosage experiments provided evidence that $\mathrm{HR}$ is a consequence of fungal growth arrest (Görg et al. 1993). In Mla-specified resistance, a haustorium maturation-associated onset of the HR has been described (Koga et al. 1990). Data that prove cell death to be a causal event of Mla-type resistance are still lacking.

In this study, we use barley coleoptiles for a functional analysis of race-specific resistance controlled by Mla-1, Mla12, and Mlg. Coleoptiles can be partially dissected, leaving the inner epidermis intact. The remaining epidermal cell monolayer, which is homologous to the natural target tissue for the powdery mildew fungus, is useful for a kinetic in vivo analysis of the infection process (Beckhove et al. 1996; Bushnell et al. 1967; Bushnell and Liu 1994; Takamatsu et al. 1978). Several reports demonstrated the ability of cereal coleoptiles to execute defense responses in a resistance genedependent manner (Bayles and Aist 1987; Bushnell and Liu 1994; Gold et al. 1986). However, our initial observations of race-specific resistance responses suggested that some of the genes were nonfunctional in coleoptiles (U. Beckhove, B. Jarosch, R. Schiffer, and K.-H. Kogel, unpublished data). A subsequent microscopic analysis showed that in those cases coleoptiles had failed to mount an HR. Thus, coleoptiles might be a valuable tool in differentiating between necessary and dispensable defense responses of barley to powdery mildew attack.

\section{RESULTS}

\section{Comparative analysis of Mla-1-, Mla-12-, and Mlg- mediated resistance responses with barley leaves and coleoptiles.}

Previous reports have indicated qualitative parallels of defense responses to the barley powdery mildew fungus in barley leaves and detached coleoptiles (Tomiyama 1982). To test whether these findings are broadly applicable to race-specific interactions, we have examined defense responses in Mla-1-, Mla-12-, and Mlg-specified resistance in near-isogenic barley lines. A rough inspection of Mla-12- and Mlg-mediated de- fense responses in the host cell attacked first revealed considerable differences between leaf tissue and coleoptiles in response to mildew attack. This was particularly evident by an apparent absence of host cell death (single-cell HR) in coleoptile tissue. We decided to compare infection phenotypes more closely, macroscopically at late stages and microscopically at early stages after inoculation in both tissues.

The macroscopic evaluation of infection phenotypes on leaves 7 days after inoculation with two races carrying the corresponding avirulence ( $a v r$ ) genes revealed complete absence of sporulating and aerial fungal mycelium in Mla-1, Mla-12, and Mlg near-isogenic genotypes (Table 1). No differences were recorded if the resistance responses were triggered by the same resistance genes but in two different genetic backgrounds (near-isogenic lines in cvs. Pallas and Ingrid). Surprisingly, coleoptile tissue from the Mla-12 near-isogenic lines showed a high degree of mycelium formation and sporulation (infection type 4), indicating that Mla-12 resistance is not expressed in this organ. In contrast, the function of Mla-1 appeared to be partially retained (infection type 2-3) and the function of $M l g$ almost fully retained (infection type 0-1; Table 1).

In accordance with previous cytological investigations (Boyd et al. 1995; Görg et al. 1993; Kita et al. 1981; Koga et al. 1990), we found that the infection phenotypes governed by resistance genes Mla-1, Mla-12, and Mlg are each associated with the onset of HR in the host cell attacked first at early time points after inoculation in leaf tissue (Fig. 1A,C,E). However, attacked coleoptile cells from Mla-12 and Mlg lines did not reveal this defense response whereas a significant portion of attacked cells of Mla- 1 coleoptiles showed the characteristic HR (Fig. 1B,D,F). The qualitative microscopic inspection of plant-fungus interaction sites in coleoptile tissue revealed, identical to the interaction in primary leaf tissue (Görg et al. 1993; Koga et al. 1990), that fungal development proceeds to the formation of haustoria only in the presence of Mla-1 and Mla-12 whereas in the presence of Mlg the pathogen is arrested at an earlier stage in cell wall appositions.

Quantitative analysis of attempted mildew infections confirmed these observations and demonstrated that an establishment of fungal haustoria occurred only rarely in $M l g$-resistant coleoptiles when inoculated with the avirulent race A6 (Fig. 2). At $48 \mathrm{~h}$ after inoculation, $85 \%$ of plant-fungus interaction sites were associated with an arrest of the fungus in papillae (penetration resistance). This corresponded with a low (15\%) frequency of haustorium formation. No HR was detected as judged by the absence of whole cell autofluorescence and retained cytoplasmic streaming in attacked cells. Since race A6 showed on coleoptile tissue of the near-isogenic susceptible line Pallas a high frequency of haustorium formation (47\%) and a correspondingly low frequency of fungal arrest in papillae $(53 \%)$, we concluded that the observed cell wall penetration-associated resistance is governed by the $M l g$ locus. In contrast, fungal penetration frequencies into coleoptile cells are not significantly different between the susceptible Pallas line and the near-isogenic resistant Mla-1 and Mla-12 lines after inoculation with avirulent races $\mathrm{C} 15$ and $\mathrm{A} 6$, respectively (Fig. 2). On Mla-1 coleoptiles, however, approximately one third of the cells containing a haustorium revealed an HR, whereas essentially no attacked cell on Mla-12 coleoptiles died in response to fungal penetration (Fig. 2). If infection 
sites on Mla-1 coleoptiles were associated with an HR, fungal development ceased as indicated by a reduction of the length of elongated secondary hyphae in comparison to sites lacking an HR (data not shown). Hence, the results obtained by recording early steps of mildew infections on coleoptiles reflect the outcome of the interactions as determined by macroscopic scoring at late time points (Table 1).

\section{Differential inhibition of race-specific resistance responses by cordycepin.}

The outcome of the above described experiments prompted us to examine more closely the role of the single-cell HR in race-specific, incompatible interactions in barley leaves. We used an in planta application of the transcriptional inhibitor cordycepin (3'-deoxyadenosine) that has been used in previous studies of several plant-pathogen interactions to inhibit resistance responses (Bushnell and Liu 1994; Tani and Yamamoto 1978; Woods et al. 1989). Since powdery mildew is an ectoparasite growing on the leaf surface, the inhibitor can be applied from an aqueous solution via the transpiration stream of detached seedlings without being in immediate, direct, physical contact with the fungus (see Materials and Methods).

Initially, dose response experiments were carried out with the Mla-12 resistant genotype to determine an effective inhibitor dose. Mla-12 confers arrest of fungal development during haustorium differentiation that is correlated with the onset of a single-cell HR in penetrated cells within $48 \mathrm{~h}$ after inoculation (Görg et al. 1993). Thus, it is possible to measure simultaneously haustorium formation and single-cell HR as a function of inhibitor dosage in single plant-fungus interaction sites on fixed leaves (Fig. 3). The experiment revealed three separable dose ranges. Concentrations lower than $4.2 \mathrm{nmol}$ cordycepin per plant showed no effect on fungal development or single-cell HR, compared with mock-treated controls. In the 4.2 to $16.6 \mathrm{nmol}$ cordycepin per plant range, the frequency of single-cell HR is drastically inhibited without significant alteration of the rate of haustorium formation. As expected, higher concentrations are apparently detrimental to fungal development as indicated by a very low frequency of haustorium formation.

The absence of fungitoxicity of cordycepin on fungal development in the dose range between 4.2 and $16.6 \mathrm{nmol}$ cordycepin per plant was confirmed with susceptible nearisogenic plants of $\mathrm{cv}$. Pallas. The application of effective cordycepin concentrations showed that haustorium formation $(54.7 \%)$ is comparable to that in mock-treated plants $(50 \%)$. Although we observed at the effective cordycepin dosage in the incompatible interaction an increased length of elongated secondary hyphae in sites lacking an HR, we were unable to keep the vigor of the detached seedlings until time points (7 dpi) when the phenotypes could be scored macroscopically.

Next, near-isogenic $M l g$ resistant genotypes were inoculated with the same avirulent race A6, which also carries the corresponding avirulence function (Fig. 4A). As outlined above, $M l g$ resistance is characterized by an arrest of fungal development prior to haustorium formation in papillae and a single-cell HR of attacked host cells. We observed in the dose range from 4.2 to $16.6 \mathrm{nmol}$ cordycepin per seedling a reduction of the single-cell HR to levels detected in the compatible near-isogenic interaction (cv. Pallas; see Figure 3). The reduction of the HR frequency to background levels of $10 \%$ (dose

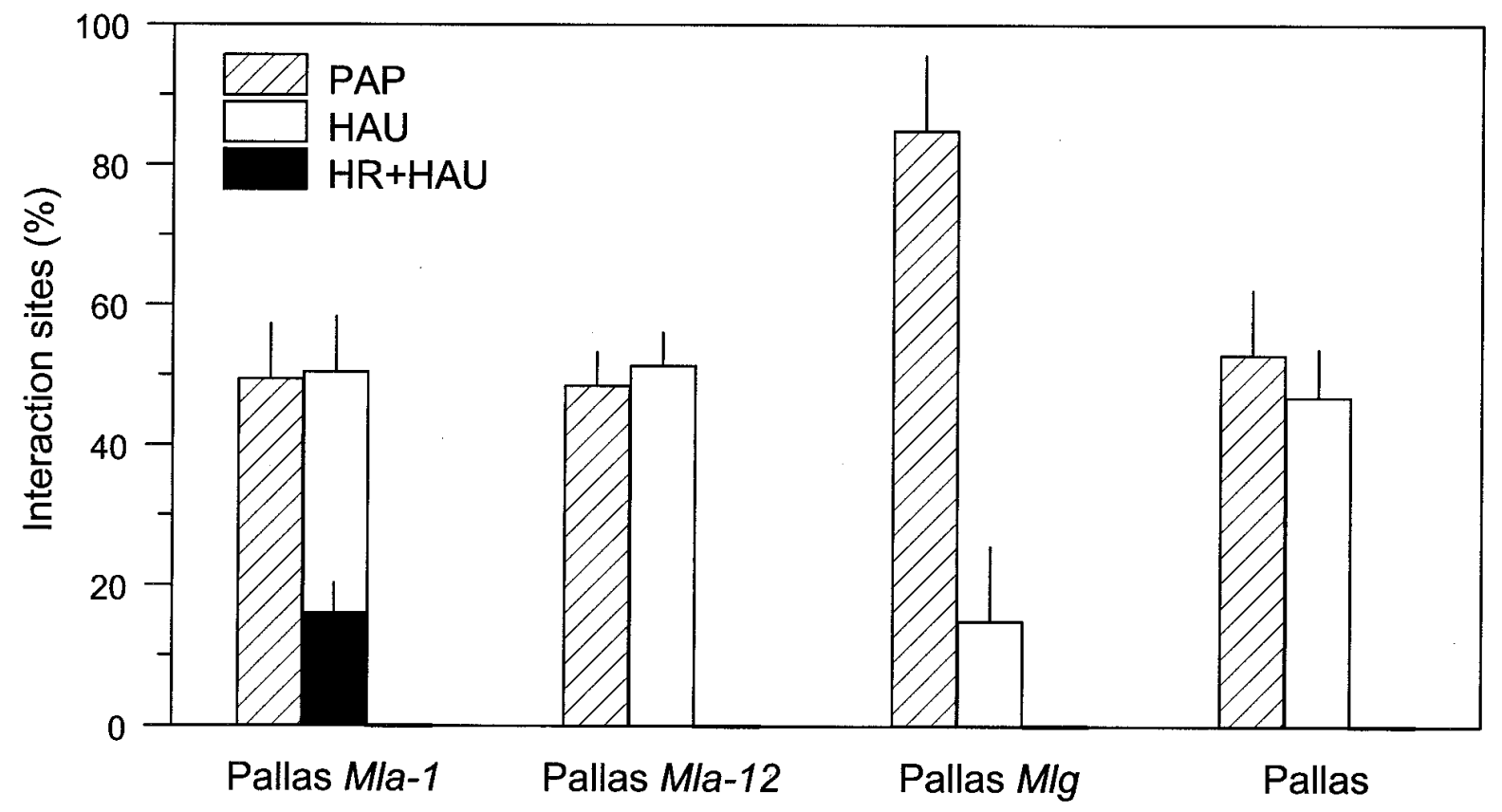

Fig. 2. Frequency of interaction sites with (effective) papillae (PAP), haustoria (HAU), and hypersensitive cell death (HR) in $M l a-1$-, $M l a-12-$, and $M l g$ mediated, single-cell resistance responses to Erysiphe graminis f. sp. hordei on epidermal monolayers prepared from barley coleoptiles. Coleoptiles were prepared from 10-day-old seedlings of the respective backcross line in cv. Pallas. Coleoptile tissue was inoculated with powdery mildew race A6 [BC Pallas Mla-12 and BC Pallas Mlg] and race C15 [BC Pallas Mla-1]. Fungal development was analyzed 48 h after inoculation. Data from a single experiment shown are based on an analysis of 250 sites of attempted infection of single cells from five coleoptiles. Data were replicated in five independent experiments. 
range 8.3 to $16.6 \mathrm{nmol}$ ) corresponds only with a minor increase in haustorium formation $(13.2 \%)$. These data parallel observations in $\mathrm{Mlg}$ coleoptiles in which a papillae-associated resistance response is retained in the absence of the single-cell HR (Fig. 1). If cordycepin was applied 8 hpi, no effect could be detected on the rate of the HR and haustorium formation (Fig. 4B). The results indicate that the $M l g$-mediated cell death reaction exhibits cordycepin sensitivity only at early time points postinoculation. Finally, preincubation experiments with cordycepin were performed by applying the inhibitor cordycepin only for a period of $6 \mathrm{~h}(-24$ to $-18 \mathrm{~h}$; Fig. $4 \mathrm{C})$. We observed again a clear reduction of the single-cell HR frequency that was not accompanied by an increased rate of haustorium formation. Thus, the inhibition of the host cell death response does not abolish growth arrest of the fungus.

We wanted to know whether the tight correlation between host cell death and whole cell autofluorescence was affected by the cordycepin treatments. We tested as an additional parameter of cell death the frequency of irreversible membrane damage in attacked host cells, by measuring their capability for neutral red uptake and plasmolysis (Table 2). Treatments with increasing doses of the inhibitor in the $M l g$ resistant genotype correlated with a parallel decrease of the frequency of nonstained/nonplasmolyzed host cells and whole cell autofluorescence in single interaction sites. Thus, whole cell auto- fluorescence even in the presence of cordycepin is a reliable indicator of cell death.

It is possible that the papillae-associated resistance component in Mlg plants and the cell death reaction exhibit a differential cordycepin sensitivity. We have previously shown by gene dosage experiments that heterozygous $M l g ~ m l g$ plants exhibit, in comparison to $\mathrm{Mlg} \mathrm{Mlg}$ genotypes, a drastic reduction of single-cell HR frequency accompanied only by a minor increase in the rate of haustorium formation (Görg et al. 1993). We wanted to know whether a decreased gene dosage of $\mathrm{Mlg}$ plus cordycepin enables the fungus to penetrate papillae more frequently (Fig. 5). Preincubations of heterozygous plants $(M l g ~ m l g)$ with the inhibitor $24 \mathrm{~h}$ before spore inoculation did not reveal a significant increase of haustorium formation, compared with mock-treated $M l g$ mlg control plants. We conclude that the papillae-associated resistance component, in contrast to the cell death component, is largely cordycepininsensitive, even in the presence of a single $M l g$ resistance allele.

\section{DISCUSSION}

We have shown here that race-specific resistance to the powdery mildew fungus involves separable defense components, by comparing host responses in two tissues (coleoptile

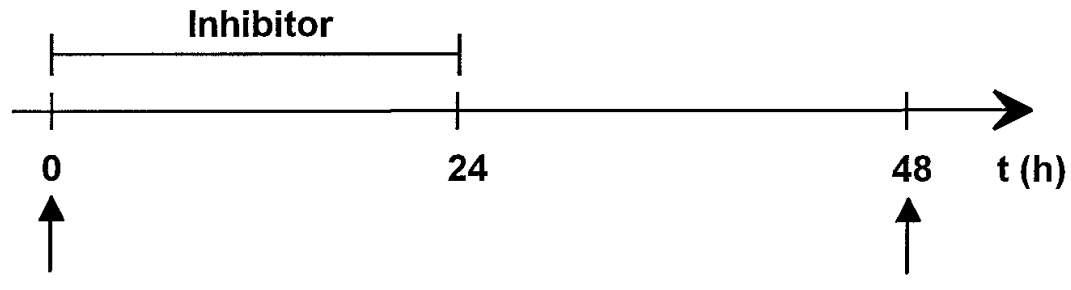

Inoculation

\section{Evaluation}

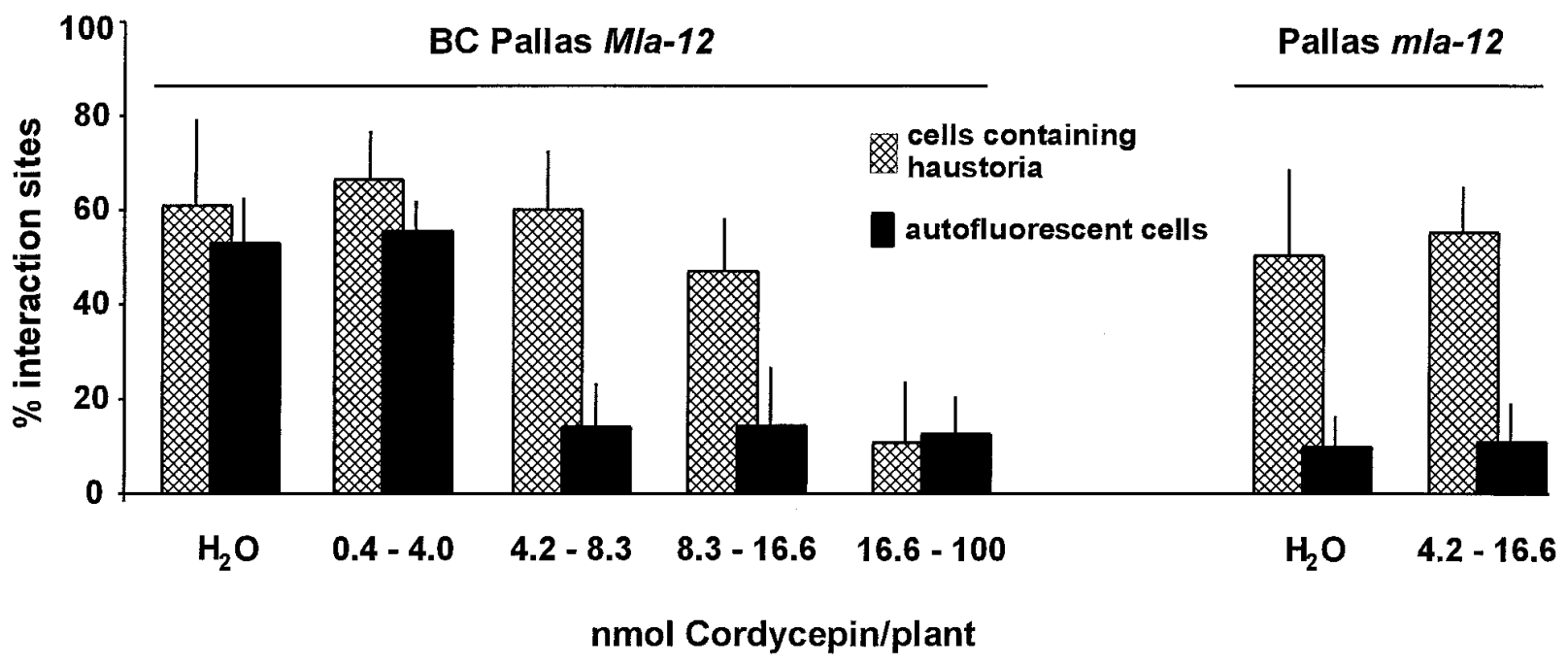

Fig. 3. Cordycepin-mediated, dose-dependent inhibition of the Mla-12-specified, single-cell hypersensitive response (HR) in primary leaf tissue. Detached seedlings of the resistant BC Mla-12 Pallas and the near-isogenic susceptible Pallas line were incubated for $24 \mathrm{~h}$ with cordycepin (graphically represented in the upper half). Seedlings were inoculated with race A6 carrying the Mla-12 avirulence function. Each data point is based on primary leaf microscopic inspection of 50 single plant-fungus interaction sites of at least five seedlings. Only small cells of the adaxial leaf surface have been considered to avoid cell-type-dependent interference due to differences in timing of fungal penetration. Since the cordycepin uptake in individual seedlings varied slightly, each data point represents a dose interval as indicated. Vertical lines indicate standard deviations. 
and epidermis of the primary leaf) and by characterizing their inhibition sensitivity in the presence of cordycepin. The data suggest that HR is likely a decisive defense event in incompatible interactions specified by Mla resistance alleles. In contrast, the HR in $M l g$-specified resistance was shown to be dispensable for fungal growth arrest. Thus, the relative impact of host cell death in race-specific resistance seems to vary depending on which particular powdery mildew resistance gene is active.

HR is a descriptive term for rapid death of host cells after challenge with an avirulent pathogen. The term was first used by Stakman (1915). HR was found to depend upon host protein synthesis (Bushnell and Liu 1994; Keen et al. 1981; Lyon and Wood 1977), and characterization of Arabidopsis mutants that spontaneously develop hypersensitive necrosis suggests the existence of a genetic program for the HR (Dietrich et al.
1994; Greenberg et al. 1994). However, it is still unclear whether HR is cause or consequence of the plant's resistance reaction (Bushnell 1982; Klement 1963; Koga et al. 1990; Tomiyama 1982; Woods et al. 1988). The problem arises because the HR is mingled with a complex network of biochemical processes executed by the plant upon pathogen attack (Bowles 1990; Collinge at al. 1994; Dixon and Harrison 1990). Although dead host cells represent a plausible barrier for the biotrophic powdery mildew fungus, whose development on the leaf surface is dependent upon host nutrient uptake through haustoria (Carver et al. 1995), additional resistance reactions different from the cell death response may be involved.

The utilization of coleoptile tissue to dissect complex resistance responses is a conceivable answer to the abovementioned problem. The monolayer prepared from detached
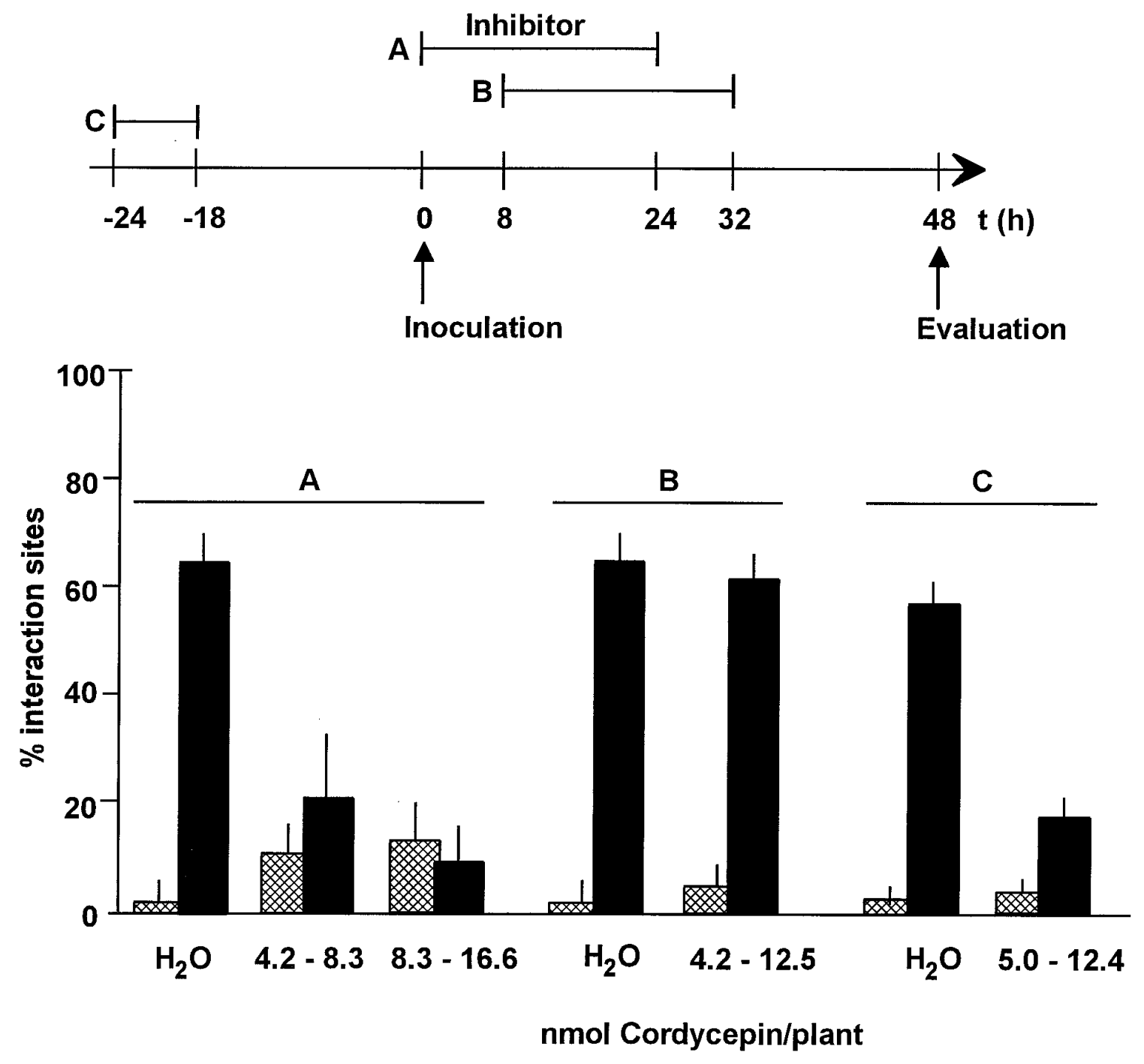

Fig. 4. Cordycepin-mediated inhibition of the Mlg-specified, single-cell hypersensitive response in primary leaf tissue. Detached seedlings of the resistant BC Mlg Pallas line were incubated for $24 \mathrm{~h}$ with cordycepin (graphically represented in the upper half). Seedlings were inoculated with race A6 carrying the Mlg avirulence function. The preincubation experiment was carried out with a 6-h cordycepin incubation period only. Each data point is based on primary leaf microscopic inspection of 50 single plant-fungus interaction sites of at least five seedlings. Only small cells of the adaxial leaf surface have been considered. Symbols are identical to those shown in Figure 3. 
coleoptiles is homologous to the natural target tissue for the powdery mildew fungus, the leaf and stem epidermal layer (Bushnell et al. 1967; Takamatsu et al. 1978). The unrestricted growth of the pathogen and the ability to complete its vegetative life cycle with the production of conidia shows that this tissue is sufficient to provide all the host components for a biotrophic interaction. In addition, coleoptiles derived from mlo genotypes execute the characteristic non-race-specific resistance to almost all tested powdery mildew races (Aist and Bushnell 1991; Bayles and Aist 1987; Gold et al. 1986) and coleoptile tissue exhibits nonhost responses (Kunoh et al. 1985). These observations, along with the fact that coleoptiles are suited for a kinetic in vivo analysis of the infection process (Beckhove et al. 1996; Mendgen 1987), make the cell monolayer a useful tool for the dissection of resistance mechanisms governed by powdery mildew resistance genes.

$M l g$ coleoptiles showed a resistant phenotype upon race A6 inoculation carrying avr Mlg, indicating the capability of the tissue to execute race/cultivar-specific resistance responses. Three lines of evidence strongly suggest that the Mlg-associated leaf epidermal HR is dispensable for growth arrest of the fungus: (i) the inhibition of the HR by cordycepin was not accompanied by a release of fungal growth arrest (i.e., formation of haustoria) on primary leaf tissue (Figs. 4 and 5); (ii) the growth arrest of A6 on Mlg coleoptiles occurred in the absence of a detectable $\mathrm{HR}$, and this has been observed in two tested genetic backgrounds (BC Mlg Pallas and BC Mlg Ingrid; Fig. 2 and data not shown); and (iii) previous gene dosage experiments showed that heterozygous $M l g$ mlg plants, in comparison to the $\mathrm{Mlg} M \mathrm{Mlg}$ genotype, exhibit a drastic reduction of single-cell HR frequency without proportional increase of haustorium formation (Görg et al. 1993).

Consistent with the above interpretation is the observation that attacked cells of $M l g$-coleoptiles retained viability (Beckhove et al. 1996). Video microscopy of single infection sites on coleoptiles attests to cytoplasmic aggregates beneath the primary and appressorial germ tube, a mobile vesicle transport directed to the aggregates, and alternated appearance and disappearance of the nucleus beneath the site of appressorial germ tube adherence. When the penetration attempt was unsuccessful, the fungus typically died approximately $48 \mathrm{~h}$ after inoculation, indicated by appressorium collapse, whereas the attacked host cell showed retained cytoplasmic streaming (U. Beckhove, K.H. Kogel, and E. Schmelzer, unpublished results).

Evidently, $M l g$ resistance is correlated with the inability of the fungus to penetrate papillae beneath the fungal appressorium. Because papillae formation is a general reaction of cereals to powdery mildew attack, the effectiveness of the papillae (e.g.,

Table 2. Correlation between whole cell autofluorescence and irreversible membrane damage in $\mathrm{Mlg}$ resistant plants

\begin{tabular}{lccc}
\hline \multirow{2}{*}{$\begin{array}{l}\text { Cordycepin } \\
\text { (nmol per plant) }\end{array}$} & $\begin{array}{c}\text { Autofluorescent } \\
\text { cells }\end{array}$ & $\begin{array}{c}\text { Nonplasmolyzed } \\
\text { cells }\end{array}$ & $\begin{array}{c}\text { Cells lacking } \\
\text { neutral red }\end{array}$ \\
\cline { 2 - 4 } & \multicolumn{3}{c}{ Per interaction site (\%) } \\
\hline 0 & 94 & 96 & 96 \\
0 & 88 & 90 & 90 \\
6.3 & 16 & 24 & 24 \\
6.4 & 32 & 38 & 38 \\
7.9 & 14 & 20 & 20 \\
8.8 & 20 & 28 & 28 \\
9.9 & 26 & 28 & 28 \\
\hline
\end{tabular}

through speed of papillae formation) rather than their formation per se seems to be controlled by Mlg. However, it is equally possible that other, yet unknown, molecular mechanism(s) confer growth arrest of the fungus in the wall appositions.

Previous investigations (Aist and Bushnell 1991; Bushnell and Liu 1994; Kita et al. 1981; Koga et al. 1990) and the data in this study indicate a crucial role for the activation of the HR in incompatible interactions controlled by the Mla locus. Absence of the HR in Mla-12 coleoptile host cells results in a fully compatible interaction (Figs. 1 and 2). A kinetic analysis of haustorium formation in the BC Mla-12 Pallas line provides no indication for delayed haustorium maturation when compared with coleoptiles from the recurrent parent cultivar Pallas (data not shown). Mature haustoria, judged by fully expanded fingerbuds, were found in either case between 32 and $48 \mathrm{~h}$ after spore inoculation in both tested genetic backgrounds
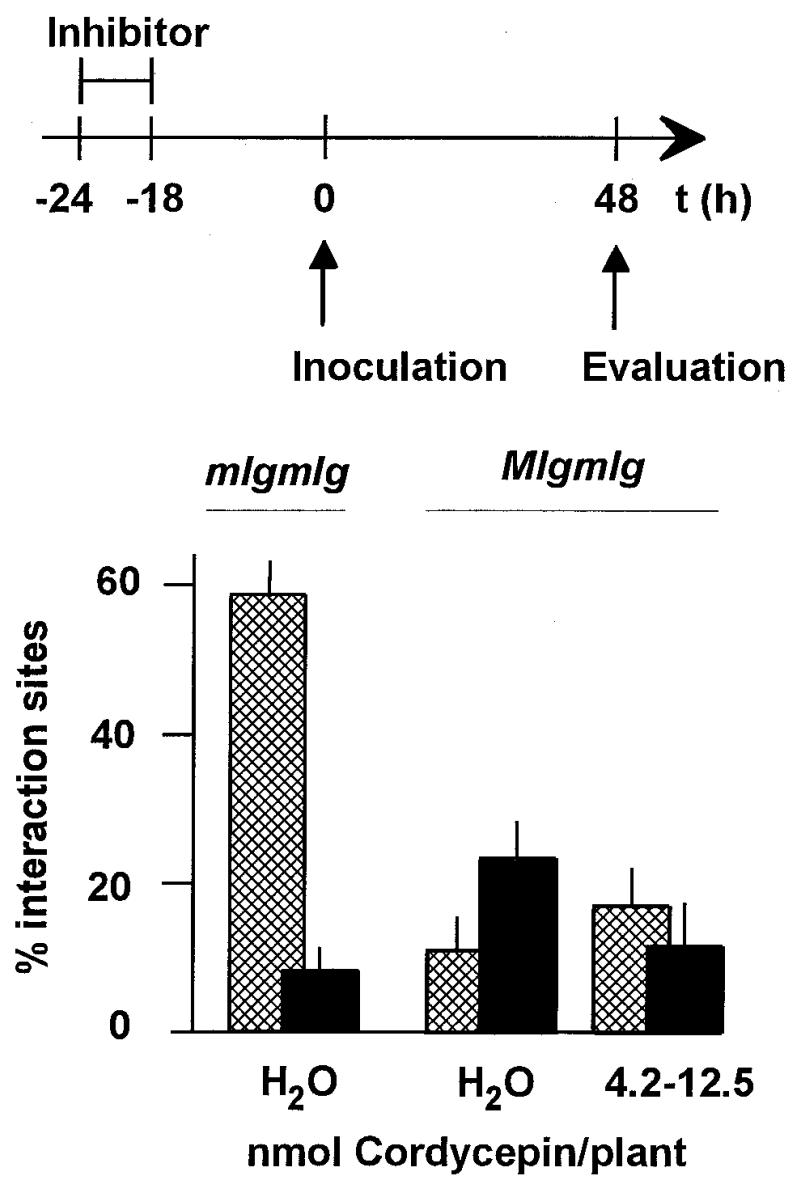

Fig. 5. Effect of $\mathrm{Mlg}$ gene dosage on the cordycepin-mediated inhibition of the single-cell hypersensitive response (HR) in primary leaf tissue. Detached $\mathrm{F}_{1}$ seedlings (Mlgmlg) of the cross $\mathrm{BC}_{7}$ Mlg Pallas $\times$ Pallas $m l g$ were incubated for $6 \mathrm{~h}$ with cordycepin prior to fungal inoculation (graphically shown in the upper half). Seedlings were inoculated with race A6 carrying the $\mathrm{Mlg}$ avirulence function. Reduction of the HR rate in the heterozygous $F_{1}$ seedlings ( 4.2 to $12.5 \mathrm{nmol}$ cordycepin per plant) to background levels found in the susceptible Pallas line is not accompanied by a proportional increase of haustorium formation. Each data point is based on primary leaf microscopic inspection of 50 single plantfungus interaction sites of at least five seedlings. Only small cells of the adaxial leaf surface were considered. Symbols are identical to those shown in Figure 3. 
(Pallas and Ingrid) of the BC Mla-12 lines (Fig. 2). Independent support for a functional role of the HR in Mla-12controlled resistance is derived from the observation that susceptible mutants carrying defects in either Mla-12 or in two genes required for its function, Rarl and Rar2, are HR deficient (Freialdenhoven et al. 1994). An inspection of nearisogenic lines carrying four Mla resistance alleles (Mla-1, Mla-3, Mla-6, and Mla-7) revealed for each line distinctive time points of fungal growth arrest during attempted infections that varied between 24 and $72 \mathrm{~h}$ after inoculation (Boyd et al. 1995). Importantly, fungal growth arrest was in each case closely associated with both the timing and the distribution of the HR. Neither the quantitative cytological studies nor the mutational analysis can exclude, however, the possibility that the loss of HR in Mla-12 coleoptiles or in the Rar mutants is the consequence of a yet unknown "upstream" resistance mechanism.

We observed an association of the Mla-1-mediated resistance response in coleoptiles with an HR (Figs. 1B and 2), qualitatively similar to a previous report of Bushnell and Liu (1994). A macroscopic evaluation of the interaction indicated, however, an intermediate resistance phenotype (Table 2). Statistical analysis of the plant responses shows that, unlike the case with primary leaf tissue, successful penetration of the fungus (scored by haustorium establishment) frequently does not trigger an HR. Instead, two thirds of cells containing a haustorium remained alive and were the basis for further development of the fungus. Hence, the cytological data (Fig. 2) are again consistent with the macroscopic evaluation of the infection types (Table 1). Since the HR is known to be environmentally contingent, we have tested various compositions of the coleoptile nutrient solution $\left(\mathrm{Ca}^{++}\right.$between 0 and 100 $\mathrm{mM}$; sucrose between 0 and $20 \mathrm{mM}$ ) but did not observe a significantly altered HR frequency. Bushnell and Liu (1994) reported an HR in almost every cell successfully penetrated by the pathogen, suggesting complete resistance in Mla- 1 coleoptiles. Although we detected no significant difference in the function of the Mla-1 allele in both host genetic backgrounds tested in this study (Table 1), the differences between our data and those of the above-mentioned authors may reflect nonidentical fungal and plant genetic material.

The cell death response specified by Mlg and Mla-12 has been shown here to be sensitive to cordycepin treatment in primary leaf tissue in a dose-dependent manner. Identical dosages were necessary in the presence of either resistance gene to inhibit HR frequency to background levels found in the compatible near-isogenic interaction (cv. Pallas; Figs. 3 and 4). Although it is known that cordycepin inhibits mRNA polyadenylation (Galling 1982; Latorre and Perry 1973), what we have not proven here is that the compound inhibits de novo mRNA synthesis in barley primary leaf tissue. Using an identical application procedure via detached seedlings, Tani and Yamamoto (1978) demonstrated in the related species oat (Avena sativa) a cordycepin-dependent reduction (90\%) of $\left[{ }^{3} \mathrm{H}\right]$ uridine incorporation into mRNA. This correlated with a substantial stimulation of fungal development of the incompatible race of Puccinia coronata f. sp. avenae in the cordycepin-treated oat seedlings. When cordycepin was applied to barley coleoptile monolayers, up to $77 \%$ reduction of incorporated radioactivity from $\left[{ }^{3} \mathrm{H}\right] \mathrm{ATP}$ into mRNA was recorded (Bushnell and Liu 1994).
The Mlg-triggered cell death response was efficiently inhibited by cordycepin without a concomitant release of fungal growth arrest to the stage of haustorium formation (Fig. 4), implying the existence of a cordycepin-insensitive component in the resistance reaction. Since fungal development is arrested at an earlier time point in Mlg genotypes than in Mla-12 genotypes (Görg et al. 1993), it could be argued that the failure to inhibit this resistance component is due to an insufficient cordycepin dose at the time point of defense activation. However, the preincubation experiments $24 \mathrm{~h}$ before pathogen inoculation (Fig. 4C) make it likely that cordycepin was active at the time point of mildew spore inoculation. Thus, the failure to release the growth arrest in cell wall appositions in the Mlg genotype is due either to an incomplete mRNA synthesis inhibition by cordycepin or to independence from de novo mRNA synthesis, i.e., a preformed resistance component. In either case, the $M l g$-triggered $\mathrm{HR}$ is not required for fungal growth arrest.

Interestingly, the HRs in coleoptile monolayers and in epidermis of the primary leaf exhibit similar characteristics although they are triggered by different resistance genes. To obtain efficient HR inhibition, cordycepin must be applied within the first $8 \mathrm{~h}$ after inoculation to Mla-1-derived coleoptile monolayers (Bushnell and Liu 1994) as well as to Mlg primary leaves (Fig. 4B). However, cordycepin was shown to be ineffective even at high dosages in inhibiting the cell death response in race-specific incompatible interactions of Lactuca sativa and Bremia lactucae (Woods et al. 1989). Therefore, we wanted to know whether our cytological measure (whole cell autofluorescence) for cell death in the presence of cordycepin might not reveal irreversible membrane damage of host cells. The retained tight correlation between whole cell autofluorescence and irreversible membrane damage (Table 2) rules out this possibility. Thus, either mRNA synthesis-dependent and -independent pathways can lead to race-specific host cell death, or cordycepin acts on different secondary target sites in Lactuca sativa and barley.

\section{MATERIALS AND METHODS}

Plants, pathogens, and inoculation.

The barley (Hordeum vulgare L.) cvs. Ingrid and Pallas as well as Mlg, Mla-1, and Mla-12 backcross lines in Ingrid and Pallas were obtained from Lisa Munk, Kopenhagen (Denmark). Their generation has been described previously (Kølster et al. 1986). The $\mathrm{BC}_{7} M l g$ Pallas line was crossed with the recurrent parent Pallas $(\mathrm{mlgmlg})$ to generate nearisogenic heterozygous $\mathrm{F}_{1}$ plants $(\mathrm{Mlgmlg})$. These plants were used for $M l g$ gene dosage experiments. Plants were grown in a growth chamber at $18^{\circ} \mathrm{C}, 80 \%$ relative humidity, and a photo period of $16 \mathrm{~h}\left(100 \mu \mathrm{E} \cdot \mathrm{s}^{-1} \cdot \mathrm{m}^{-2}\right)$. Inoculation was performed with conidia from Erysiphe graminis DC. f. sp. hordei Ém. Marchal race A6, expressing Mla-12 and Mlg avirulence, and race C15 expressing Mla-1 avirulence (Wiberg 1974).

\section{Inoculation, and macroscopic and microscopic analysis of infections of leaves.}

Macroscopic analysis was carried out with 7-day-old primary leaves. For inoculation a spore density of 2 to 6 conidia $\mathrm{cm}^{-2}$ was utilized. This very low density was necessary to obtain countable, single colonies on the leaves at late infection 
stages (7 dpi). Colonies on the adaxial and abaxial surfaces of the primary leaves were counted.

For microscopic analysis of early infection stages (48 hpi), 7-day-old primary leaves were inoculated on adaxial surfaces at conidial densities of 100 to $200 \mathrm{~cm}^{-2}$. This medium density reduced the probability of host epidermal cells being attacked by more than one conidium.

Six-centimeter leaf segments were harvested and placed into a clearance solution $(0.15 \%$ trichloroacetic acid [wt/vol] in ethyl alcohol/chloroform, 4:1 [ $\mathrm{vol} / \mathrm{vol}])$ in order to stop the development of the fungi and to remove all chlorophyll. The solution was exchanged once during the next $48 \mathrm{~h}$ of incubation. To stain fungal structures for bright field microscopy, leaf segments were stained in a freshly prepared Coomassie blue solution ( $0.6 \%$ Coomassie brilliant blue R 250 [wt/vol] in methanol/15\% trichloroacetic acid [wt/vol] in $\mathrm{H}_{2} \mathrm{O}, 1: 1$ [ $\mathrm{vol} / \mathrm{vol}]$ for $15 \mathrm{~s}$, washed in water and mounted in $50 \%$ glycerol [ $\mathrm{vol} / \mathrm{vol}]$.

Infection sites were quantitatively recorded with respect to plant responses, HR, and papilla formation, as well as distinct fungal developmental stages, formation of haustoria, and elongated secondary hyphes. Whole cell autofluorescence (HR) was observed by fluorescence microscopy $(\lambda=310 \mathrm{~nm}$; Axiophot, Zeiss, Germany). Papillae were recorded with bright field and fluorescence microscopy.

\section{Preparation, inoculation, and quantitative macroscopic and microscopic analysis of infections on coleoptiles.}

Coleoptiles were prepared from 10-day-old seedlings and partially dissected to leave the inner epidermis intact (Bushnell et al. 1967; Takamatsu et al. 1978). Both of the cut ends of coleoptiles were attached to small pieces of adhesive vinyltape. The inner (noncuticularized) surface was exposed to a nutrient solution containing $10 \mathrm{mM} \mathrm{Ca}\left(\mathrm{NO}_{3}\right)_{2}$ and kept for 14 to $18 \mathrm{~h}$ at $20^{\circ} \mathrm{C}$ under $200 \mathrm{~lx}$ fluorescent light. Subsequently, the outer (cuticularized) epidermal surface of the coleoptile was inoculated with freshly harvested conidia, using a spore density of 2 to 6 conidia $\mathrm{mm}^{-2}$. Under these conditions, Egh completes its vegetative life cycle within 5 days after inoculation. Macroscopy and microscopy were done as with leaves.

\section{Cordycepin treatment of detached seedlings.}

Transpiration stream-mediated in planta application of aqueous inhibitor solutions was performed with similar sized, detached, 7-day-old seedlings placed in 1.5-ml Eppendorf reaction tubes (modified according to Tani and Yamamoto 1978). Seedlings were incubated in $1 \mathrm{ml}$ of inhibitor solution (10 to $250 \mu \mathrm{M}$ cordycepin in $\mathrm{H}_{2} \mathrm{O}$ ) in a phytochamber under the conditions described above. At the end of the various inhibitor incubation times, seedlings were transferred to Eppendorf tubes containing water; $48 \mathrm{~h}$ after inoculation, 6-cm leaf segments were harvested and fixed as described above. The amount of inhibitor uptake (nmol inhibitor per plant) was calculated separately for each seedling on the basis of the residual volume measured immediately after inhibitor incubation (the uptake was corrected for evaporation by simultaneous incubation of $1 \mathrm{ml}$ of $\mathrm{H}_{2} \mathrm{O}$ without seedling in each experiment). Microscopic analysis of single plant-fungus interaction sites was carried out as described above; the analysis included for each data point at least five seedlings. A total of 50 interaction sites were inspected per seedling.
Analysis of irreversible membrane damage.

Irreversible membrane damage analysis was carried out by published protocols (Koga et al. 1988; Woods et al. 1988). Infiltration of osmoticum and neutral red-staining were carried out as described previously (Görg et al. 1993).

\section{ACKNOWLEDGMENTS}

The work was supported by the Bundesministerium für Forschung Technologie, Bildung und Wissenschaft to K.-H. K. and by the Deutsche Forschungsgemeinschaft to P. S.-L (Schwerpunktprogramm "Molekulare Phytopathologie"). We are grateful to R. Gold and E. Schmelzer for their kind assistance in coleoptile analysis.

\section{LITERATURE CITED}

Aist, J. R., and Bushnell, W. R. 1991. Invasion of plant hosts by powdery mildew fungi, and cellular mechanism of resistance. Pages 321345 in: The Fungal Spore and Disease Initiation in Plants and Animals. G. T. Cole and H. C. Hoch, eds. Plenum, New York.

Aist, J. R., and Israel, H. W. 1986. Autofluorescence and ultravioletabsorbing components in cell walls and papillae of barley coleoptiles and their relationship to disease resistance. Can. J. Bot. 64:266-272.

Anderson, J. B., and Torp, J. 1986. Quantitative analysis of early powdery mildew infection stages on resistant barley genotypes. J. Phytopathol. 115:173-186.

Bayles, C. J., and Aist, J. R. 1987. Apparent calcium mediation of resistance of an $m l-o$ barley mutant to powdery mildew. Physiol. Mol. Plant Pathol. 30:337-345.

Beckhove, U., Kogel, K. H., and Schmelzer, E. 1996. Acquired resistance in barley: Early accumulation of the potentiometric dye DIOC $_{6}$ in cytoplasmic aggregations beneath the primary germ tube of Erysiphe graminis f.sp. hordei in barley coleoptiles induced by 2,6dichloroisonicotinic acid. Pages 475-481 in: Modern Fungicides and Antifungal Compounds. H. Lyr, P. E. Russel, and H. D. Sisler, eds. Intercept, Andover.

Bowles, D. J. 1990. Defense-related proteins in higher plants. Annu. Rev. Biochem. 59:873-907.

Boyd, L. A., Smith, P. H., Foster, E. M., and Brown, J. K. M. 1995. The effects of allelic variation at the Mla resistance locus in barley on the early development of Erysiphe graminis f.sp. hordei and host responses. Plant J. 7:959-968.

Bushnell, W. R. 1982. Hypersensitivity in rusts and mildews. Pages 97116 in: Plant Infection: The Physiological and Biochemical Basis. Y. Asada, W. R. Bushnell, S. Ouchi, and C. P. Vance, eds. Jpn. Sci. Soc. Press, Tokyo.

Bushnell, W. R., Dueck, J., and Rowell, J. B. 1967. Living haustoria and hyphae of Erysiphe graminis f.sp. hordei with intact and partly dissected host cells of Hordeum vulgare. Can. J. Bot. 45:1719-1732.

Bushnell, W. R., and Liu, Z. 1994. Incompatibility conditioned by the mla gene in powdery mildew of barley: Timing of the effect of cordycepin on hypersensitive cell death. Physiol. Mol. Plant Pathol. 43: 389-402.

Carver, T. L. W. 1988. Pathogenesis and host-parasite interaction in cereal powdery mildew. Pages 351-381 in: Experimental and Conceptual Plant Pathology. R. S. Singh, U. S. Singh, W. M. Hess, and D. J. Weber, eds. Gordon and Breach, New York.

Carver, T. L. W., Ingerson-Morris, S. M., Thomas, B. J., and Zeyen, R. J. 1995. Early interactions during powdery mildew infection. Can. J. Bot. 73:632-639.

Collinge, D. B., Gregersen, P. L., and Thordal-Christensen, H. 1994. The induction of gene expression in response to pathogenic microbes. Pages 391-433 in: Mechanisms of Plant Growth and Improved Productivity: Modern Approaches and Perspectives. A. S. Basra, ed. Marcel Dekker, New York.

Dietrich, R. A., Delaney, T. P., Ukness, S. J., Ward, E. R., Ryals, J. A., and Dangl, J. L. 1994. Arabidopsis mutants simulating disease resistance. Cell 77:565-577.

Dixon, R. A., and Harrison, M. J. 1990. Activation, structure and organization of genes involved in microbial defense in plants. Adv. Genet. 28:165-234.

Ellingboe, A. H. 1972. Genetics and physiology of primary infection by Erysiphe graminis. Phytopathology 62:401-406. 
Flor, H. H. 1971. Current status of the gene for gene concept. Annu. Rev. Phytopathol. 9:275-296.

Freialdenhoven, A., Scherag, B., Hollricher, K., Collinge, D. B., Thordal-Christensen, H., and Schulze-Lefert, P. 1994. Nar-1 and Nar-2, two loci required for Mla12-specified race-specific resistance to powdery mildew in barley. Plant Cell 6:983-994.

Galling, G. 1982. Use (and misuse) of inhibitors in gene expression. Pages 663-677 in: Nucleic Acids and Proteins in Plants. II. Encyclopedia of Plant Physiology (New Series) Vol. 14B. B. Parthier and D. Boulter, eds. Springer Verlag, New York.

Gold, R. E., Aist, J. R., Hazen, B. E., Stolzenburg, M. C., Marshall, M. R., and Israel, H. W. 1986. Effects of calcium nitrate and chlortetracycline on papilla formation, $m l-o$ resistance and susceptibility of barley to powdery mildew. Physiol. Mol. Plant Pathol. 29:115-129.

Görg, R., Hollricher, K., and Schulze-Lefert, P. 1993. Functional analysis and RFLP-mediated mapping of the Mlg resistance locus in barley. Plant J. 3:857-866.

Greenberg, J. T., Guo, A., Klessig, D. F., and Ausubel, F. M. 1994. Programmed cell death in plants: A pathogen-triggered response activated coordinately with multiple defence functions. Cell 77: 551-563.

Keen, N. T., Ersek, T., Long, M., Bruegger, R., and Holliday, M. 1981. Inhibition of the hypersensitive reaction of soybean leaves to incompatible Pseudomonas spp. by blasticidin S, streptomycin or elevated temperature. Physiol. Plant Pathol. 18:325-337.

Kita, N., Toyoda, H., and Shishiyama, J. 1981. Chronological analysis of cytological responses in powdery-mildewed barley leaves. Can. J. Bot. 59:1761-1768.

Klement, Z. 1963. Rapid detection of the pathogenicity of phytopathogenic pseudomonads. Nature 199:299-300.

Koga, H., Bushnell, W. R., and Zeyen, R. J. 1990. Specificity of cell type and timing of events associated with papilla formation and the hypersensitive reaction in leaves of Hordeum vulgare attacked by Erysiphe graminis f.sp. hordei. Can. J. Bot. 68:2344-2352.

Koga, H., Zeyen, R. J., Bushnell, W. R., and Ahlstrand, G. G. 1988. Hypersensitive cell death, autofluorescence, and insoluble silicon accumulation in barley leaf epidermal cells under attack by Erysiphe graminis f.sp. hordei. Physiol. Mol. Plant Pathol. 32:395-409.

Kølster, P., Munk, L., Stølen, O., and Løhde, J. 1986. Near-isogenic barley lines with genes for resistance to powdery mildew. Crop Sci. 26:903-907.

Kunoh, H., Aist, J. R., and Hayashimoto, A. 1985. The occurrence of cytoplasmic aggregates induced by Erysiphe pisi in barley coleoptile cells before the host cell walls are penetrated. Physiol. Plant Pathol. 26:199-207.

Latorre, J., and Perry, R. P. 1973. The relationship between polyadenylated heterogenous nuclear RNA and messenger RNA: Studies with actinomycin D and cordycepin. Biochem. Biophys. Acta 335:93-101.

Lyon, F. M., and Wood, R. K. 1977. Alteration of response of bean leaves to compatible and incompatible bacteria. Ann. Bot. (London) 41:359-367.

Mendgen, K. 1987. Infektion und Wirtsreaktion beim Gerstenmehltau. Publikationen zu wissenschaftichen Filmen, Section Biologie, Serie 19, Nr. 19, FILM C 1642, Institut für den wissenschaftlichen Film, Göttingen.

Stakman, E. C. 1915. Relation between Puccinia graminis and plants highly resistant to its attack. J. Agric. Res. 4:193-200.

Tani, T., and Yamamoto, H. 1978. Nucleic acid and protein synthesis in association with the resistance of oat leaves to crown rust. Physiol Plant Pathol. 12:113-121.

Takamatsu, S., Ishizaki, H., and Kunoh, H. 1978. Cytological studies of early stages of powdery mildew in barley and wheat. V. Effects of calcium on the infection of coleoptiles of barley by Erysiphe graminis hordei. Can. J. Bot. 56:2544-2549.

Tomiyama, K. 1982. Hypersensitive cell death: Its significance and physiology. Pages 329-344 in: Plant Infection: The Physiological and Chemical Basis. Y. Asada, W. R. Bushnell, S. Ouchi, and C. P. Vance, eds. Jpn. Sci. Soc. Press, Tokyo.

Wiberg, A., 1974. Genetical studies of spontaneous sources of resistance to powdery mildew in barley. Hereditas 77:89-148.

Woods, A. M., Fagg, J., and Mansfield, J. W. 1988. Fungal development and irreversible membrane damage in cells of Lactuca sativa undergoing the hypersensitive reaction to the downy mildew fungus Bremia lactucae. Physiol. Mol. Plant Pathol. 32:483-497.

Woods, A. M., Fagg, J., and Mansfield, J. W. 1989. Effects of heat-shock and inhibitors of protein synthesis on irreversible membrane damage occurring during the hypersensitive reaction of Lactuca sativa L. to Bremia lactucae. Physiol. Mol. Plant Pathol. 34:531-544. 